\title{
JAK MIERZYĆ PRZYJAZNOŚĆ PRZESTRZENI DLA RUCHU PIESZEGO?
}

\section{How to measure urban space walkability?}

\author{
Joanna Jaczewska \\ Zakład Rozwoju Regionalnego, Instytut Geografii, Wydział Oceanografii i Geografii, Uniwersytet Gdański, Bażyńskiego 4, 80-309 Gdańsk \\ e-mail: joanna.jaczewska@ug.edu.pl
}

Cytacja:

Jaczewska J., 2019, Jak mierzyć przyjazność przestrzeni dla ruchu pieszego?, Prace Komisji Geografii Komunikacji PTG, 22(4), 25-33.

Streszczenie: Chociaż transport pieszy jest najbardziej podstawowym i naturalnym środkiem przemieszczania się ludzi, to w XX w. stracił gwałtownie na znaczeniu w oczach projektantów za sprawą koncepcji modernistycznych i dynamicznego rozwoju motoryzacji. W ostatnich latach obserwuje się zmianę postrzegania ruchu pieszego i nadawanie mu priorytetowego charakteru. Jak dowodzą najnowsze badania, projektowanie zorientowane na wygodę pieszych wpływa pozytywnie nie tylko na zrównoważony rozwój miast, ale też na aktywność fizyczną mieszkańców oraz ich zdrowie fizyczne i psychiczne. Jednak w jaki sposób ocenić, czy przestrzeń jest przyjazna dla ruchu pieszego? W ostatnich latach pojawiło się wiele badań nad tą problematyką, próbujących określić stopień wpływu poszczególnych czynników na aktywność fizyczną ludzi. Prezentowany artykuł jest systematyzacją aktualnych koncepcji mierzenia przyjazności przestrzeni dla ruchu pieszego na podstawie literatury przedmiotu, w szczególności dwóch przekrojowych studiów porównawczych podsumowujących stan wiedzy na ten temat. W artykule omówiono kluczowe metody pomiaru, ich zalety, jak też potencjalne ograniczenia. W podsumowaniu przedstawiono możliwe aplikacje wyników badań oraz przedstawiono kierunki rozwoju metod badawczych. Konieczna jest weryfikacja stosowanych metod w warunkach polskich, uwzględniająca lokalne uwarunkowania. W celu zapewnienia porównywalności wyników postuluje się standaryzację wskaźników, uwzględnianie czynników wewnętrznych, mogących wpływać na zróżnicowanie poziomu aktywności fizycznej, jak też wykorzystanie do jej mierzenia dużych zbiorów danych (Big Data).

Słowa kluczowe: jakość życia w mieście, przyjazność dla ruchu pieszego, ruch pieszy, transport zrównoważony

\begin{abstract}
Walking as the elementary and most natural transport mode is often viewed as neglected. In the course of the 20th century it has lost its significance due to modernist visions and the dynamic development of motor vehicles. In the recent years we observe a change in the way walking is perceived and the resulting prioritizing of it as a transport system. As recent research studies make evident, pedestrians-oriented urban projects facilitate sustainable development of cities and prove to have a positive impact on the physical activity of the inhabitants and their overall health. That raises the question: how to evaluate the walkability of a specific space? Recently, a number of research studies have attempted to determine the degree of impact that particular factors exercise on human physical activity. The present article systematises recent concepts of walkability measurement on the basis of the relevant literature and, in particular, on the basis of two cross-sectional comparative papers that bring together the dispersed knowledge on the subject. The article considers the key measurement methods as well as their advantages and potential limitations. In the summary possible applications of research results and outlooks for research methods have been proposed. It is necessary to verify the methods used in the Polish local conditions. In order to secure more comparability of results the author claims a standardisation of indicators, as well as inclusion of internal factors that might influence the differentiation of walking behaviours. Finally, making use of big data is recommended.
\end{abstract}

Key words: sustainable transport, pedestrian traffic, urban quality of life, walkability 


\section{Wstęp}

Chodzenie pieszo jest najstarszym i najbardziej naturalnym środkiem transportu. Do niedawna traktowane było w planowaniu miast jako drugorzędny sposób przemieszczania się, wybierany z konieczności (Olszewski, 2007). W ostatnich latach podejście to zaczęło się zmieniać, ponieważ dostrzeżono pozytywny wpływ chodzenia na zrównoważony rozwój miast oraz zdrowie człowieka (Olszewski, 2007). Zakrojone na wielką skalę projekty modernistyczne XX w. znacząco wpłynęły na projektowanie systemu komunikacji w miastach. Idee modernizmu wraz z dynamicznym rozwojem motoryzacji przynajmniej na kilka dziesięcioleci zaanektowały przestrzeń miast dla transportu kołowego, który stał się priorytetowym środkiem przemieszczania się (Gehl, 2017). Współcześnie następuje odwrót od takiego planowania. Jeden z bardziej wpływowych ruchów we współczesnej urbanistyce, czyli Nowy Urbanizm, odwołuje się do wartości miasta tradycyjnego, propaguje planowanie dostosowane do skali człowieka, sprzyjające ruchowi pieszemu (Cysek-Pawlak, 2018). Projektowanie zorientowane raczej na wygodę pieszych, niż użytkowników samochodów, służy zrównoważonemu rozwojowi obszarów miejskich poprzez zmniejszanie zanieczyszczenia, kongestii, ograniczenie liczby wypadków, redukowanie kosztów utrzymania czy oszczędzanie przestrzeni miejskiej (Cysek-Pawlak, 2018).

Aktualne badania wskazują na to, że przyjazność danego obszaru dla pieszych wpływa nie tylko na zrównoważony rozwój terenów miejskich, zapewniając mieszkańcom lepsze miejsce do życia, ale także bezpośrednio determinuje ich zdrowie psychiczne i fizyczne (Wang, Yang, 2019). Mieszkańcy obszarów sprzyjających chodzeniu pieszo są bardziej aktywni fizycznie, mają niższy wskaźnik masy ciała, mniejsze ryzyko wystąpienia chorób sercowo-naczyniowych, cukrzycy czy depresji (Berke i in., 2007; Frank i in., 2006; Saelens i in., 2003; Wang, Yang, 2019). Przyjazność przestrzeni dla ruchu pieszego może wpływać również na jakość środowiska, jak choćby poprawę jakości powietrza (Frank i in., 2006; Marshall i in., 2009), oraz wzrost i bardziej zrównoważony charakter lokalnej gospodarki czy tworzenie bardziej inkluzywnych społeczności (Ellis i in., 2015; Litman, 2003).

$\mathrm{Na}$ indywidualne wybory dotyczące chodzenia pieszo wpływa szereg różnych czynników - cechy "wewnętrzne" (takie jak wiek, sprawność, upodobania), jak i „zewnętrzne” - środowisko, w którym dana jednostka żyje. Stopień, w jakim środowisko fizyczne sprzyja chodzeniu, bywa określany angielskim terminem walkability (Frank i in., 2006; Nosal, 2017; Wang, Yang 2019). Ze względu na brak adekwatne- go odpowiednika w języku polskim, w tłumaczeniu wykorzystuje się opisowe określenie „przyjazność dla ruchu pieszego" (Nosal, 2017). Koncepcja walkability została po raz pierwszy przedstawiona w latach 90. ubiegłego wieku (Southworth, Owens, 1993). Obecnie badania nad tą cechą przestrzeni zyskują coraz większą popularność. Temat ten poruszany jest z perspektywy zdrowia publicznego, nauki o środowisku i ekologii, jak też geografii i urbanistyki (Wang, Yang, 2019). Podobnie jak w wielu innych krajach, w Polsce ukazały się w ostatnich latach artykuły poruszające tę tematykę od strony teoretycznej i praktycznej (Cichocka, 2015; Nosal, 2017; Nosal i in., 2017; Waloska, Nosal, 2018).

Ze względu na kluczową rolę, jaką w dalszym rozwoju omawianych badań odgrywa konstrukcja wskaźników służących do mierzenia wpływu środowiska zabudowanego na aktywność fizyczną, w niniejszym artykule omówione zostały kluczowe sposoby ich doboru i metody mierzenia. Celem prezentowanego artykułu jest zarysowanie zasadniczych tendencji w rozwoju metodyki badania walkability i wskazanie, na podstawie przeglądu najbardziej reprezentatywnej i syntetycznej literatury, jakie warunki muszą zostać spełnione, aby badacze mierzyli to, co naprawdę chcą mierzyć. Wyodrębniono zasadnicze różnice i podobieństwa między opisywanymi metodami, jak też ograniczenia w ich stosowaniu. W tym celu sięgnięto do literatury polskiej i zagranicznej, aby jak najpełniej przedstawić aktualnie wykorzystywane w nauce koncepcje, w szczególności opierając się na dwóch przekrojowych studiach porównawczych podsumowujących stan wiedzy na temat walkability (Brownson i in., 2009; Wang, Yang, 2019).

\section{Czynniki wpływające na wybór transportu pieszego}

Jak wyżej wspomniano, na wybór transportu pieszego wpływają czynniki wewnętrzne i zewnętrzne. Choć termin „przyjazność przestrzeni dla ruchu pieszego" odnosi się do czynników określonych wyżej jako zewnętrzne, to prowadząc analizy nie należy zapominać również o kontrolowaniu zmiennych indywidualnych, które mogą wpływać na intensywność podróży pieszych. W literaturze można spotkać się z rozbudowanym katalogiem mierników mających określać stopień przyjazności miasta dla pieszych. Jednymi z najczęściej wykorzystywanych są te, które wiążą się $z$ dostępnością podstawowych funkcji oraz gęstością powiązań drogowych, umożliwiającą szybkie i bezpośrednie przejście między punktami docelowymi (Ellis i in., 2015; Wang, Yang 2019). Oprócz tego wyróżnia się też takie czynniki jak: gęstość zamieszkania, zróżnicowanie użytkowania gruntów, 
bezpieczeństwo oraz wysoką jakość przestrzeni (Brownson i in., 2009; Ellis i in., 2015; Wang, Yang, 2019). W tab. 1 znajduje się propozycja systematyzacji wykorzystywanych w literaturze czynników w podziale na kategorie. Wśród czynników wewnętrznych wyodrębnione zostały cechy fizyczne, społeczno-ekonomiczne oraz kulturowe. Z kolei wśród czynników zewnętrznych wydzielono uwarunkowania naturalne, układ przestrzenny, infrastrukturę pieszą, punkty docelowe i funkcje, jak też zieleń, bezpieczeństwo i estetykę. Do każdej z kategorii przypisane zostały przykładowe czynniki, które mogą mieć wpływ na wybór podróży pieszych.
(Brownson i in., 2009). Na przykład, gęstość zabudowy mieszkaniowej można oszacować poprzez zadanie respondentowi serii pytań dotyczących budynków znajdujących się w okolicy. Można również wykonać audyt za pomocą obserwacji na miejscu albo dokonać analiz przestrzennych z wykorzystaniem narzędzi GIS, aby wyliczyć dokładną gęstość zabudowy. W tab. 2 przedstawione zostały poszczególne kategorie czynników oraz przykłady ich wykorzystania w wybranych artykułach badawczych. Każda z kategorii ma potencjalne zalety poznawcze i ograniczenia.

Pierwsza omawiana kategoria obejmuje metody oparte na subiektywnej ocenie. Chodzi tu

Tab. 1. Potencjalne czynniki wpływające na wybór transportu pieszego.

\begin{tabular}{|c|c|c|}
\hline Rodzaj & Kategoria & Przykładowe czynniki \\
\hline \multirow{3}{*}{$\begin{array}{l}\text { Wewnętrzne } \\
\text { (Indywidualne) }\end{array}$} & Fizyczne & płeć, wiek, zdrowie, sprawność fizyczna itd. \\
\hline & Społeczno-ekonomiczne & wykształcenie, zawód, dochód, sytuacja rodzinna, posiadanie samochodu itd. \\
\hline & Kulturowe & styl życia, upodobania, system wartości itd. \\
\hline \multirow{7}{*}{$\begin{array}{l}\text { Zewnętrzne } \\
\text { (Środowiskowe) }\end{array}$} & Uwarunkowania naturalne & ukształtowanie terenu, nachylenia, bariery naturalne, klimat itd. \\
\hline & Układ przestrzenny & $\begin{array}{l}\text { gęstość zabudowy mieszkaniowej, proporcje przestrzeni, długość kwartałów, } \\
\text { wysokość budynków, gęstość powiązań sieci drogowej itd. }\end{array}$ \\
\hline & Infrastruktura piesza & $\begin{array}{l}\text { szerokość chodników, stan infrastruktury pieszej, udogodnienia dla pieszych } \\
\text { itd. }\end{array}$ \\
\hline & Punkty docelowe/ funkcje & $\begin{array}{l}\text { zróżnicowanie użytkowania terenów, dostępność do konkretnych usług } \\
\text { podstawowych, miejsc pracy, rekreacji itd. }\end{array}$ \\
\hline & Zieleń & obecność zieleni, drzew, dużych skupisk roślinności itd. \\
\hline & Bezpieczeństwo & $\begin{array}{l}\text { bezpieczeństwo w ruchu drogowym, natężenie ruchu, prędkość } \\
\text { samochodów, bezpieczeństwo związane z przestępczością, obecność innych } \\
\text { ludzi, zanieczyszczenia, hałas itd. }\end{array}$ \\
\hline & Estetyka & $\begin{array}{l}\text { ład przestrzenny, porządek i czystość, interesujące obiekty, atrakcyjne } \\
\text { budynki, widoki itd. }\end{array}$ \\
\hline
\end{tabular}

Źródło: opracowanie własne.

\section{Dobór metod mierzenia przyjazności przestrzeni dla pieszych}

Wiedza o poszczególnych czynnikach zewnętrznych zależy w dużej mierze od źródeł pozyskiwania danych. R. Brownson i in. (2009) wyróżnili trzy typy najczęściej wykorzystywanych metod pomiaru cech środowiska zewnętrznego. Typy te odnoszą się do różnych źródeł wiedzy o czynnikach wpływających na przyjazność przestrzeni: 1) subiektywnej oceny deklarowanej przez jednostki na podstawie własnej percepcji; 2) ustandaryzowanej obserwacji odnoszącej się do audytu w przestrzeni czy materiałów audiowizualnych, albo 3) obiektywnej analizy z wykorzystaniem narzędzi GIS na podstawie danych istniejących zwłaszcza o liczne metody ankietowe. Posługują się one narzędziem w postaci kwestionariusza ankiety W wielu krajach do mierzenia przyjazności okolicy dla ruchu pieszego służy kwestionariusz NEWS (The Neighborhood Environment Walkability Scale). Obejmuje on siedem głównych kategorii czynników opisanych w tab. 3. Kwestionariusz w podstawowej formie składa się z 68 pytań, omawiając zagadnienia związane z gęstością zamieszkania, zróżnicowaniem użytkowania gruntów, gęstością połączeń ulicznych, występowaniem udogodnień dla pieszych, estetyką i bezpieczeństwem. W tab. 3 przedstawiony został sposób operacjonalizacji poszczególnych czynników. W przypadku czynników odnoszących się do bardziej konkretnych atrybutów przestrzeni 
Tab. 2. Trzy podstawowe metody pomiaru środowiska zewnętrznego.

\begin{tabular}{|c|c|l|l|l|}
\hline Lp. & Kategoria & \multicolumn{1}{|c|}{ Przykładowe narzędzie } & \multicolumn{1}{|c|}{ Metoda } & \multicolumn{1}{c|}{ Przykładowe artykuły } \\
\hline 1 & Subiektywna ocena & $\begin{array}{l}\text { Skala przyjazności środowiska } \\
\text { sąsiedzkiego dla pieszych (NEWS } \\
- \text { The Neighborhood Environment } \\
\text { Walkability Scale) }\end{array}$ & Kwestionariusz & $\begin{array}{l}\text { (Cerin i in., 2006; Leslie i in., 2005; ze } \\
\text { zmianami: Rosenberg i in., 2009) }\end{array}$ \\
\hline 2 & $\begin{array}{c}\text { Ustandaryzowana } \\
\text { obserwacja }\end{array}$ & $\begin{array}{l}\text { Ocena walorów urbanistycznych } \\
\text { przestrzeni (Urban design } \\
\text { qualities) }\end{array}$ & $\begin{array}{l}\text { Panel ekspercki, } \\
\text { zdjęcia/ filmy }\end{array}$ & (Ewing, Handy, 2009; Ewing i in., 2006) \\
\hline 3 & Obiektywna analiza & $\begin{array}{l}\text { Indeks przyjazności dla pieszych } \\
\text { (Walkability index) }\end{array}$ & $\begin{array}{l}\text { GIS, dane } \\
\text { przestrzenne }\end{array}$ & $\begin{array}{l}\text { (Frank i in., 2005; Frank i in., 2009; Frank } \\
\text { i in., 2006; Manaugh, 2011; Marshall, 2009; } \\
\text { Owen i in., 2007; Leslie i in., 2005; Leslie i in., } \\
\text { 2007) }\end{array}$ \\
\hline
\end{tabular}

Źródło: opracowanie własne na podstawie podziału zaproponowanego przez: Brownson i in., 2009.

(takich jak obecność chodnika przy każdej ulicy) rzetelność pomiaru bywa wyższa, niż przy aspektach raczej wrażeniowych. Należy zauważyć, że percepcja przestrzeni w niewielkim stopniu koresponduje z jej standaryzowaną oceną (Boehmer i in., 2006), co może wynikać $z$ różnic indywidualnych, jak również z wielkości danej społeczności (Brownson i in., 2009). Kluczowe pozostaje wszakże pytanie, czy na zachowania jednostek wpływają obiektywnie mierzalne charakterystyki przestrzeni, czy też może to, jak owa jednostka je postrzega. Przykładem może być poczucie bezpieczeństwa. Nawet jeżeli nie ma żadnych obiektywnych racji na rzecz przekonania, że okolica jest niebezpieczna, to jeżeli dana osoba bę- dzie czuła się zagrożona, nie ma pewności, co będzie silniej warunkować jej zachowanie: obiektywny stan rzeczy, czy własne odczucia. Zwłaszcza w przypadku estetyki - jakże ważnej w nadawaniu miastu właściwego mu charakteru - można dowodzić, że percepcja jest $w$ istocie rzeczywistością (Brownson i in., 2009). Wymaga to dalszych badań, w których należałoby zestawiać ze sobą dane subiektywne i obiektywne, żeby lepiej zidentyfikować faktyczny wpływ danych czynników na walkability.

Przygotowując się do realizacji badań ankietowych, należy uwzględnić szereg kwestii związanych z metodologią prowadzenia takich badań, jak m.in. dobór próby, trudności w jej realizacji (poziom zwrotu

Tab. 3. Czynniki mierzone metodą ankietową - na przykładzie kwestionariusza NEWS (The Neighborhood Environment Walkability Scale).

\begin{tabular}{|c|c|c|}
\hline Lp. & Czynnik & Operacjonalizacja \\
\hline 1 & $\begin{array}{l}\text { Gęstość mieszkalna (Residential } \\
\text { density) }\end{array}$ & $\begin{array}{l}\text { Dominujący rodzaj zabudowy mieszkaniowej w okolicy (np. zabudowa jednorodzinna, } \\
\text { szeregowa, wielorodzinna - z podziałem na liczbę pięter) }\end{array}$ \\
\hline 2 & $\begin{array}{l}\text { Zróżnicowanie użytkowania } \\
\text { gruntów (Land-use mix) }\end{array}$ & $\begin{array}{l}\text { Bliskość czasowa dojścia pieszego do konkretnych punktów docelowych (np. } \\
\text { podstawowych usług, pracy, szkoły). Przekonania na temat dostępności: usług, miejsc } \\
\text { parkingowych, występowanie naturalnych barier (wzgórza, kaniony), zróżnicowanie } \\
\text { wysokości terenu }\end{array}$ \\
\hline 3 & $\begin{array}{l}\text { Gęstość połączeń ulicznych (Street } \\
\text { connectivity) }\end{array}$ & $\begin{array}{l}\text { Możliwość dojścia różnymi drogami w to samo miejsce, niewielka liczba ślepych uliczek, } \\
\text { niewielkie odległości pomiędzy skrzyżowaniami }\end{array}$ \\
\hline 4 & $\begin{array}{l}\text { Udogodnienia piesze, rowerowe } \\
\text { (Walking/cycling facilities) }\end{array}$ & $\begin{array}{l}\text { Obecność chodnika przy każdej ulicy, stan chodników, bliskość tras pieszych i rowerowych, } \\
\text { oddzielenie chodników od jezdni parkingami, pasami zielni }\end{array}$ \\
\hline 5 & Estetyka (Aesthetics) & $\begin{array}{l}\text { Obecność drzew, zacienienia, interesujące obiekty skupiające uwagę, ład przestrzenny, } \\
\text { atrakcyjne budynki, atrakcyjne otwarcia widokowe, krajobraz }\end{array}$ \\
\hline 6 & $\begin{array}{l}\text { Bezpieczeństwo ruchu pieszego } \\
\text { (Pedestrian/automobile traffic } \\
\text { safety) }\end{array}$ & $\begin{array}{l}\text { Natężenie ruchu samochodów, dopuszczalna prędkość, przekraczanie prędkości, } \\
\text { dostępność sygnalizacji świetlnej, przejść dla pieszych w miejscach bardziej uczęszczanych, } \\
\text { zanieczyszczenia }\end{array}$ \\
\hline 7 & $\begin{array}{l}\text { Bezpieczeństwo dotyczące } \\
\text { przestępczości (Crime safety) }\end{array}$ & $\begin{array}{l}\text { Oświetlenie ulicy, dobra widoczność ulicy z okien domów mieszkalnych, wchodzenie } \\
\text { w interakcje z sąsiadami, wskaźnik przestępczości }\end{array}$ \\
\hline
\end{tabular}

Źródło: opracowanie na podstawie: Cerin i in., 2006 i Leslie i in., 2005. 
kwestionariuszy lub odmów odpowiedzi) czy też zasoby potrzebne do przeprowadzenia badania (ludzkie, finansowe i czasowe).

Kolejna metoda dająca szansę na zwiększenie trafności pomiarów to zarazem najstarsza metoda naukowa, czyli obserwacja, która podnosi stopień standaryzacji otrzymywanych wyników. Aby zmi- cyjnych można mierzyć również wiele innych czynników, które nie zawsze są możliwe do weryfikacji innymi metodami. Jest to m.in. jakość przestrzeni, stan budynków, obecność elementów zaburzających ład publiczny, głośność w przestrzeni czy dostosowanie przestrzeni do potrzeb osób o ograniczonych zdolnościach ruchowych.

Tab. 4. Czynniki użyte do oceny jakości miejskiej przestrzeni (Urban design qualities).

\begin{tabular}{|c|l|l|}
\hline Lp. & \multicolumn{1}{|c|}{ Czynniki } & \multicolumn{1}{c|}{ Operacjonalizacja } \\
\hline 1 & Malowniczość (imageability) & $\begin{array}{l}\text { Liczba osób, odsetek zabytkowych budynków, liczba dziedzińców, placów i parków, } \\
\text { obecność ogródków restauracyjnych na świeżym powietrzu, liczba budynków } \\
\text { o nieprostokątnych sylwetkach, poziom hałasu, liczba głównych cech krajobrazu, liczba } \\
\text { budynków z cechami szczególnymi }\end{array}$ \\
\hline 2 & Domknięcie (enclosure) & $\begin{array}{l}\text { Proporcja ścian przestrzeni po obu stronach ulicy, proporcje widocznego nieba - po } \\
\text { bokach i na wprost, liczba linii widokowych }\end{array}$ \\
\hline 3 & Skala ludzka (human scale) & $\begin{array}{l}\text { Liczba linii widokowych, liczba elementów małej architektury i innych obiektów, proporcje } \\
\text { pierwszego piętra z oknami, wysokość budynków, liczba małych donic }\end{array}$ \\
\hline 5 & Przejrzystość (transparency) & $\begin{array}{l}\text { Proporcje pierwszego piętra z oknami, odsetek aktywnych użytkowników, proporcja ściany } \\
\text { ulicy }\end{array}$ \\
\hline Złożoność (complexity) & $\begin{array}{l}\text { Liczba osób, liczba dominujących kolorów na budynkach, liczba budynków, obecność } \\
\text { ogródków restauracyjnych na świeżym powietrzu, liczba akcentów kolorystycznych, liczba } \\
\end{array}$ \\
\hline
\end{tabular}

Źródło: opracowanie na podstawie: Ewing, Handy, 2009 i Ewing i in., 2006.

nimalizować różnice pomiędzy percepcją różnych obserwatorów, obserwacja jest wykonywana wedle ściśle określonej procedury. Nie wszystkie informacje mogą być zresztą dostarczone przez osoby niebędące ekspertami, niekoniecznie zaznajomione z definicjami czy abstrakcyjnymi terminami dotyczącymi jakości przestrzeni. Obserwatorzy często poddawani są specjalistycznym szkoleniom prowadzonym do momentu osiągnięcia przez nich wysokiego poziomu zgodności co do oceny określonych zagadnień (Brownson i in., 2009). W praktyce obserwacje polegają najczęściej na audytach wykonywanych przez przeszkolonych badaczy poruszających się pieszo lub przejeżdżających przez pewien fragment przestrzeni.

Jednym z przykładów zastosowania metody ustandaryzowanej oceny przestrzeni, jest przedstawiona w tab. 4, technika oceny jakości przestrzeni miejskiej (Urban design qualities measure). Wykorzystuje się $w$ tym przypadku oceny $z$ panelu ekspertów, którzy zoperacjonalizowali pięć walorów urbanistycznych: malowniczość, domknięcie, ludzką skalę, przejrzystość i złożoność. Definicje operacyjne służące do oceny ilościowej nie zawsze są zgodne z intuicyjnymi definicjami jakościowymi tychże walorów (Ewing, Handy, 2009). Za pomocą metod obserwa-
Ostatnią analizowaną kategorią metod są analizy przestrzenne. W przypadku badania wielu cech środowiska fizycznego wydają się charakteryzować wysoką adekwatnością. Mogą obejmować wiele fragmentów przestrzeni i mierzyć je za pomocą różnych, precyzyjnie określonych skal.

Jedną z częściej stosowanych metod do mierzenia walkability zaproponował L. Frank i in. (2009). Zaproponowany przez autorów indeks, składający się z czterech podstawowych czynników, został przedstawiony w tab. 5. Jego składowe to: gęstość zamieszkania, gęstość połączeń ulicznych, zróżnicowanie użytkowania gruntów oraz intensywność zabudowy handlowej. Jak można zauważyć na podstawie tab. 5, czynniki te ograniczają się do ogólnych cech środowiska urbanistycznego, pomijając bardziej szczegółowe aspekty środowiska zewnętrznego, jak chociażby jakość infrastruktury pieszej, natężenie ruchu kołowego czy bezpieczeństwo.

Jeżeli chodzi o potencjały i ograniczenia metod analiz przestrzennych, należy zauważyć, że wymagają one potencjalnie mniejszych nakładów czasowych i osobowych w porównaniu do wcześniej omawianych metod dzięki temu, że dają możliwość pozyskiwania danych ze źródeł wtórnych i automatyzacji analiz. Pozostaje jednak problem niedostatecznej 
Tab. 5. Szczegółowe czynniki wykorzystywane w Walkability index.

\begin{tabular}{|c|l|l|}
\hline Lp. & \multicolumn{1}{|c|}{ Czynnik } & \multicolumn{1}{c|}{ Operacjonalizacja } \\
\hline 1 & $\begin{array}{l}\text { Gęstość zamieszkania netto } \\
\text { (Net residential density) }\end{array}$ & Liczba gospodarstw domowych w stosunku do powierzchni terenów mieszkalnych \\
\hline 2 & $\begin{array}{l}\text { Gęstość połączeń ulicznych } \\
\text { (Street connectivity) }\end{array}$ & Liczba skrzyżowań (co najmniej trzylinie łączące się w punkcie) na km² \\
\hline 3 & $\begin{array}{l}\text { Zróżnicowanie użytkowania } \\
\text { gruntów (Land-use mix) }\end{array}$ & $\begin{array}{l}\text { Wskaźnik równomiernego rozłożenia powierzchni terenów a) mieszkalnych, b) } \\
\text { handlowych, c) rekreacyjnych (z gastronomią), d) biurowych oraz e) usług publicznych (np. } \\
\text { szkoły) }\end{array}$ \\
\hline 4 & $\begin{array}{l}\text { Intensywność zabudowy } \\
\text { handlowej (Retail floor area ratio) }\end{array}$ & $\begin{array}{l}\text { Powierzchnia użytkowa budynków handlowych podzielona przez powierzchnię terenów } \\
\text { handlowych }\end{array}$ \\
\hline
\end{tabular}

Źródło: opracowanie na podstawie: Frank i in., 2005 i Frank i in., 2009.

jakości danych, braków danych i różnic pomiędzy źródłami danych (Brownson i in., 2009). Problemem może być również duże zróżnicowanie między badaczami w zakresie operacjonalizacji poszczególnych zmiennych, co powodować może znaczną trudność w porównywaniu między sobą wyników badań (Brownson i in., 2009). Inne zauważone przez R.C. Brownsona i in. (2009) problemy to różnice w podejściach badaczy do uzupełniania braków danych, konieczność podjęcia decyzji o sposobie radzenia sobie z nimi (np. imputowanie danych) oraz rozbieżność czasowa w tworzeniu poszczególnych zbiorów danych. Analizowanie zbiorów pochodzących z różnych punktów czasowych może oznaczać, że przedmiotem analizy jest rzeczywistość skonstruowana przez badacza (Brownson i in., 2009).

Ostatnim wymagającym omówienia problemem, który dotyczy analiz przestrzennych jest kwestia skali wykonywania analiz. Jak zauważa R. C. Brownson (2009), jednostki analizy są bardzo różnie wybierane. Mogą to być obszary administracyjne, obręby spisowe, obszar wytyczony w linii prostej od określonego punktu (tak zwany bufor), lub obszar wytyczony na podstawie dystansu wzdłuż ciągów komunikacyjnych czyli przedstawiający najbardziej adekwatny obszar możliwego przejścia w różnych kierunkach, ponieważ uwzględnia bariery (Brownson i in., 2009). Ważną kwestią jest przy tym przyjmowana odległość, bowiem zbyt duży bufor może uwzględniać nieistotne z perspektywy jednostki uwarunkowania, natomiast zbyt mały może część z nich pomijać. Zasięg poddawany analizie $w$ badaniach zawiera się $w$ przedziale od 400 do 3200 m (Brownson i in., 2009), co ma odpowiadać możliwym do pokonania dystansom pieszym. Odległość brana pod uwagę $w$ analizach powinna jednak uwzględniać choćby specyfikę badanych grup społecznych (np. osoby starsze) lub uwarunkowania lokalne (np. dostęp do terenów rekreacyjnych).
Ciekawą, alternatywną wobec analiz GIS, metodą jest numeryczny wskaźnik Walk Score, występujący jako publicznie dostępna aplikacja internetowa (Carr i in., 2010a). Aplikacja powstała w 2007 r., wykonana została przez firmę z Seattle - docelowo na potrzeby rynku nieruchomości. Zaczęła być brana pod uwagę jako potencjalny, prosty miernik przyjazności przestrzeni dla pieszych i porównywana z innymi metodami (Carr i in., 2010a; 2010b; Duncan i in., 2011). Bierze ona pod uwagę tylko jeden wskaźnik - odległość do konkretnych usług. Dzieli je na 13 podstawowych kategorii: a) sklepy spożywcze, b) kawiarnie, c) restauracje, d) bary, e) kina, f) szkoły, g) parki, h) biblioteki, i) księgarnie, j) centra fitness, k) drogerie, l) sklepy z narzędziami, m) sklepy z odzieżą / muzyką. Każda kategoria jest ważona, a punkty z każdej z nich są sumowane w taki sposób, że wynik mieści się pomiędzy wartościami 0-100.

Wymienione narzędzie korzysta z aplikacji Google AJAX Search API (application program interface), wyszukując znajdujące się w okolicy obiekty usługowe (Carr i in., 2010a). Współczynnik wyliczany jest na podstawie odległości danego obiektu od analizowanego punktu. Algorytm przypisuje wyższe wartości obiektom znajdującym się bliżej, zaś niższe znajdującym się dalej (Manaugh, El-Geneidy, 2011). Wskaźnik ten był weryfikowany w szeregu badań w Stanach Zjednoczonych i jest uznawany za trafny sposób mierzenia dostępności usług, a nawet szacowania gęstości zaludnienia (Carr i in., 2010a; Carr i in., 2010b; Duncan i in., 2011; Manaugh, El-Geneidy, 2011). Ze względu na fakt, że narzędzie to bazuje na informacjach znajdujących się w sieci, możliwość jego wykorzystania jest znacznie ograniczona w krajach, gdzie informacje o usługach nie są tak dostępne w Internecie. Innym problemem podnoszonym przez L. Carra i jego zespół (2010b) jest pozytywna korelacja wskaźnika Walk Score ze zgłoszonymi przestępstwa- 
mi. W tym zakresie potrzebne są dalsze badania i weryfikacja tego wskaźnika w polskich warunkach.

\section{Podsumowanie}

W artykule przedstawione zostały główne podejścia do mierzenia wpływu czynników środowiska zewnętrznego na aktywność ludzi. W dalszym ciągu brakuje ustandaryzowanych metod obiektywnego mierzenia środowiska zabudowanego (Brownson i in., 2009; Wang, Yang, 2019). W badaniach bierze się pod uwagę wiele cech, które bez wątpienia mają dużo wspólnego z przyjaznością przestrzeni dla ruchu pieszego, lecz nie wyjaśniają całościowo tej cechy środowiska. W tab. 66 przedstawiono podsumowanie trzech podstawowych metod badawczych. Jak można zauważyć, w pewnym sensie stanowią one komplementarne źródła wiedzy. Mimo ogromnych zalet metod analiz przestrzennych z wykorzystaniem narzędzi GIS, mają one także pewne ograniczenia, przez co nie mogą stanowić samowystarczalnej metody oceny środowiska zabudowanego.

Jak piszą H. Wang i Y. Yang (2019), w dalszym ciągu nie został zidentyfikowany wpływ poszczególnych czynników na przyjazność przestrzeni dla pieszych, jak też, wzajemne oddziaływanie czynników na siebie. Problemowi temu można starać się zaradzić, wykorzystując różne metody, biorące pod uwagę ków wewnętrznych może wpłynąć na lepsze dopasowanie modeli wpływu środowiska na zachowania ludzi. Konieczne może się okazać analizowanie tych czynników w różnych skalach, bo mogą się różnić w odniesieniu do różnych populacji. Inaczej doświadczają samej możliwości ruchu osoby młode i aktywne, a inaczej seniorzy.

Zadaniem dla przyszłych badań nad walkability byłaby weryfikacja wykorzystywanych do tej pory metod, często niestosowanych jeszcze w Polsce lub pozostających w początkowej fazie rozwoju. Jak zauważa K. Nosal (2017), uwzględniając czynniki gospodarcze, kulturowe czy socjologiczne, należałoby dążyć do dopasowania metod do lokalnej specyfiki. $Z$ drugiej strony nie należy zapominać o standaryzacji metod, by możliwe było porównywanie i wychwytywanie różnic kulturowych pomiędzy różnymi obszarami, a co za tym idzie, formułowanie generalizacji pozwalających czerpać z doświadczeń innych krajów i obszarów.

Jak podają H. Wang i Y. Yang (2019), jedną z kwestii, które trzeba wziąć pod uwagę, jest również jakość danych o aktywności. Najczęściej są one zbierane na podstawie deklaracji uczestników ruchu. Należy jednak zwrócić uwagę na możliwe błędy pomiaru czy odchylenia wynikające z niewłaściwych założeń badania (Wang, Yang, 2019). Wraz z rozwojem nowoczesnych technologii wielu badaczy testuje metody

Tab. 6. Ocena trzech podstawowych metod pomiaru środowiska zewnętrznego.

\begin{tabular}{|c|c|c|c|}
\hline Lp. & Metoda & Zalety & Wady \\
\hline 1 & $\begin{array}{l}\text { Subiektywna ocena } \\
\text { (kwestionariusz) }\end{array}$ & $\begin{array}{l}\text { Bezpośrednie powiązanie danych o aktywności, } \\
\text { zmiennych demograficznych ze sposobem } \\
\text { postrzegania przestrzeni, dostęp do subiektywnych } \\
\text { odczuć (poczucia bezpieczeństwa, estetyki) }\end{array}$ & $\begin{array}{l}\text { Duże nakłady zasobów (ludzkich, czasowych, } \\
\text { finansowych), niejednoznaczne oceny cech } \\
\text { fizycznych przestrzeni }\end{array}$ \\
\hline 2 & $\begin{array}{c}\text { Ustandaryzowana } \\
\text { obserwacja }\end{array}$ & $\begin{array}{l}\text { Możliwość eksperckiej oceny charakteru } \\
\text { przestrzeni (np. ludzka skala, domknięcie, } \\
\text { różnorodność architektoniczna), dane są } \\
\text { bardziej ustandaryzowane niż w metodach } \\
\text { kwestionariuszowych, możliwość oceny przestrzeni, } \\
\text { ładu przestrzennego, stanu technicznego, czy } \\
\text { dostępności dla różnych grup }\end{array}$ & $\begin{array}{l}\text { Większe nakłady zasobów (ludzkich, } \\
\text { czasowych i finansowych) w porównaniu do } \\
\text { metod GIS }\end{array}$ \\
\hline 3 & $\begin{array}{l}\text { Obiektywna analiza } \\
\text { (narzędzia GIS) }\end{array}$ & $\begin{array}{l}\text { Łatwy dostęp do danych, możliwość analizowania } \\
\text { dużych obszarów, automatyzacja analiz, } \\
\text { ustandaryzowanie wyników, metoda dobrze } \\
\text { sprawdza się w ocenie aspektów urbanistycznych }\end{array}$ & $\begin{array}{l}\text { Niedostateczna jakość danych, problem } \\
\text { aktualności, spójności czasowej zbiorów, } \\
\text { niezdolność do analizowania aspektów takich } \\
\text { jak ład przestrzenny, estetyka, różnorodność } \\
\text { architektoniczna }\end{array}$ \\
\hline
\end{tabular}

Źródło: opracowanie własne.

zarówno czynniki obiektywne, jak i subiektywne. Dalsza praca analityczna pozwoli z pewnością lepiej zrozumieć wpływ poszczególnych cech przestrzeni na ludzką aktywność, szczególne efekty synergii lub sprzężenia zwrotne. Ponadto, uwzględnienie czynni- pozyskiwania danych o aktywności także z innych źródeł, takich jak wielkie zbiory danych (Big Data). Dodatkowe dane mogą zostać pozyskane z aplikacji zainstalowanych na telefonach komórkowych, aby określać rzeczywiste korzystanie z przestrzeni (Ya- 
magata, Seya, 2019), inni badacze próbują wykorzystać zasób danych z Google Street View, analizując zdjęcia za pomocą algorytmów samouczących się (Yin i in., 2015). Jeszcze innym podejściem może być też zautomatyzowana analiza nagrań z monitoringu miejskiego rejestrująca rzeczywiste przepływy ludzi w określonych punktach (Hipp i in., 2015).

Badania nad walkability, dzięki identyfikacji kluczowych czynników odpowiedzialnych za stymulowanie aktywności oraz wpływu tych czynników na jakość życia mieszkańców, mogą dostarczać istotnych argumentów na rzecz określonego kształtowania polityk lokalnych i krajowych poprzez wyznaczenie kierunków zmian w rozwoju miast, jak również (docelowo) w określaniu warunków prawnych wpływających na kształtowanie przestrzeni. Identyfikacja kluczowych czynników walkability jest bezpośrednio związana z opracowywaniem bardziej adekwatnych zasad projektowania urbanistycznego. Bezpośrednio też modele takie mogą zostać wykorzystane do wspomagania procesu projektowego. Dobrym przykładem są wykonywane już teraz próby generatywnej optymalizacji w projektowaniu przestrzennym (por. Cichocka, 2015). Oprócz tego analizowane są różne metody aplikacji tych analiz - w postaci map wyliczania przyjazności przestrzeni - które mogą posłużyć do wyszukiwania przez mieszkańców najlepszych miejsc do życia, tym samym zwiększając świadomość zainteresowanych i potencjalnie wywołując oddolny nacisk użytkowników na kształt przestrzeni (por. Lwin, Murayama, 2011).

\section{Piśmiennictwo}

Berke E.M., Gottlieb L.M., Moudon A.V., Larson E.B., 2007, Protective Association Between Neighborhood Walkability and Depression in Older Men, Journal of the American Geriatrics Society, 55(4), 526-533. (DOI 10.1111/j.1532-5415.2007.01108.x)

Brownson R.C., Hoehner C.M., Day K., Forsyth A., Sallis J.F., 2009, Measuring the Built Environment for Physical Activity, American Journal of Preventive Medicine, 36(4), 99-S123. (DOI 10.1016/j.amepre.2009.01.005)

Boehmer T.K., Hoehner C.M., Wyrwich K.W., Ramirez L.K.B., Brownson R.C., 2006, Correspondence between Perceived and Observed Measures of Neighborhood Environmental Supports for Physical Activity, Journal of Physical Activity and Health, 3(1), 22-36. (DOI 10.1123/ jpah.3.1.22)

Carr L.J., Dunsiger S.I., Marcus B.H., 2010a, Validation of Walk Score for estimating access to walkable amenities, British Journal of Sports Medicine, 45(14), 1144-1148. (DOI: 10.1136/bjsm.2009.069609)

Carr L.J., Dunsiger S.I., Marcus B.H., 2010b, Walk Score ${ }^{\mathrm{TM}}$ As a Global Estimate of Neighborhood Walkability, Ameri- can Journal of Preventive Medicine, 39(5), 460-463. (DOI 10.1016/j.amepre.2010.07.007)

Cichocka J., 2015, Generatywna optymalizacja w planowaniu przestrzennym - koncept miasta przyjaznego ruchowi pieszemu, Architectus, 1(41), 119-128.

Cerin E., Saelens B.E., Sallis J.F., Frank L.D., 2006, Neighborhood Environment Walkability Scale: Validity and Development of a Short Form, Medicine \& Science in Sports \& Exercise, 38(9), 1682-1691. (DOI 10.1249/01. mss.0000227639.83607.4d)

Cysek-Pawlak M.M., 2018, Increased density as a new urbanism principle for urban regeneration, Przestrzeń i Forma, 36, 141-158.

Duncan D.T., Aldstadt J., Whalen J., Melly S.J., Gortmaker S.L., 2011, Validation of Walk Score ${ }^{\circledR}$ for Estimating Neighborhood Walkability: An Analysis of Four US Metropolitan Areas, International Journal of Environmental Research and Public Health, 8, 4160-4179. (DOI 10.3390/ ijerph8114160)

Ellis G., Hunter R., Tully M. A., Donnelly M., Kelleher L, Kee F., 2015, Connectivity and physical activity: using footpath networks to measure the walkability of built environments, Environment and Planning B: Planning and Design, 43(1), 130-151. (DOI 10.1177/0265813515610672)

Ewing R., Handy S., 2009, Measuring the Unmeasurable: Urban Design Qualities Related to Walkability, Journal of Urban Design, 14(1), 65-84. (DOI 10.1080/13574800802451155)

Ewing R., Handy S., Brownson R.C., Clemente O., Winston, E., 2006, Identifying and Measuring Urban Design Qualities Related to Walkability, Journal of Physical Activity and Health, 3(s1), 223-S240. (DOI 10.1123/jpah.3.s1.s223)

Frank L.D., Schmid T.L., Sallis J.F., Chapman J., Saelens B.E., 2005, Linking objectively measured physical activity with objectively measured urban form, American Journal of Preventive Medicine, 28(2), 117-125. (DOI 10.1016/j. amepre.2004.11.001)

Frank L.D., Sallis, J.F., Conway T.L., Chapman J.E., Saelens B.E., Bachman W., 2006, Many Pathways from Land Use to Health: Associations between Neighborhood Walkability and Active Transportation, Body Mass Index, and Air Quality, Journal of the American Planning Association, 72(1), 75-87. (DOI 10.1080/01944360608976725)

Frank L.D., Sallis J.F., Saelens B.E., Leary L., Cain K., Conway T.L., Hess P.M., 2009, The development of a walkability index: application to the Neighborhood Quality of Life Study, British Journal of Sports Medicine, 44(13), 924-933. (DOI 10.1136/bjsm.2009.058701)

Gehl J., 2017, Miasta dla ludzi, tłum. Szymon Nogalski, RAM, Kraków.Hipp J.A., Manteiga A., Burgess A., Stylianou A., Pless R., 2015, Cameras and crowds in transportation tracking, Proceedings of the Conference on Wireless Health - WH'15. (DOI 10.1145/2811780.2811941)

Leslie E., Saelens B., Frank L., Owen N., Bauman A., Coffee N., Hugo G., 2005, Residents' perceptions of walkabi- 
lity attributes in objectively different neighbourhoods: a pilot study, Health \& Place, 11(3), 227-236. (DOI 10.1016/j.healthplace.2004.05.005)

Leslie E., Coffee N., Frank L., Owen N., Bauman A., Hugo G., 2007, Walkability of local communities: Using geographic information systems to objectively assess relevant environmental attributes, Health \& Place, 13(1), 111-122. (DOI 10.1016/j.healthplace.2005.11.001)

Litman T., 2003, Economic Value of Walkability, Transportation Research Record: Journal of the Transportation Research Board, 1828, 3-11. (DOI 10.3141/1828-01)

Lwin K.K., Murayama Y., 2011, Modelling of urban green space walkability: Eco-friendly walk score calculator, Computers, Environment and Urban Systems, 35(5), 408420. (DOI 10.1016/j.compenvurbsys.2011.05.002)

Manaugh K., El-Geneidy A., 2011, Validating walkability indices: How do different households respond to the walkability of their neighborhood?, Transportation Research Part D: Transport and Environment, 16(4), 309-315. (DOI 10.1016/j.trd.2011.01.009)

Marshall J.D., Brauer M., Frank L.D., 2009, Healthy Neighborhoods: Walkability and Air Pollution, Environmental Health Perspectives, 117(11), 1752-1759. (DOI 10.1289/ehp.0900595)

Nosal K., 2017, Wybrane zagadnienia dotyczące przyjazności infrastruktury transportowej i przestrzeni publicznych dla ruchu pieszego, Transport Miejski i Regionalny, 5, 12-18.

Nosal K., Franek Ł., Rogala S., 2017, Space and Its Use for Pedestrian Traffic in Center Areas of Selected Polish Cities, Transport Economics and Logistics, 67, 45-52.

Olszewski P., 2007, Walking as a mode of transport - a planning and policy perspective, Prace Naukowe Politechniki Warszawskiej. Budownictwo, 146, 5-149.
Owen N., Cerin E., Leslie E., duToit L., Coffee N., Frank L.D., Bauman A.E., Hugo G., Saelens B.E., Sallis J.F., 2007, Neighborhood Walkability and the Walking Behavior of Australian Adults, American Journal of Preventive Medicine, 33(5), 387-395. (DOI 10.1016/j.amepre.2007.07.025)

Rosenberg D., Ding D., Sallis J.F., Kerr J., Norman G.J., Durant N., Harris S.K., Saelens B.E., 2009, Neighborhood Environment Walkability Scale for Youth (NEWS-Y): Reliability and relationship with physical activity, Preventive Medicine, 49(2-3), 213-218. (DOI 10.1016/j. ypmed.2009.07.011)

Saelens B.E., Sallis J.F., Black J.B., Chen, D., 2003, Neighborhood-Based Differences in Physical Activity: An Environment Scale Evaluation, American Journal of Public Health, 93(9), 1552-1558. (DOI 10.2105/ ajph.93.9.1552)

Southworth M., Owens P.M., 1993, The Evolving Metropolis: Studies of Community, Neighborhood, and Street Form at the Urban Edge, Journal of the American Planning Association, 59(3), 271-287. (DOI 10.1080/01944369308975880)

Waloska M., Nosal Hoy K., 2018, Analiza przyjazności dla ruchu pieszego okolic Rynku Dębnickiego w Krakowie, Transport Miejski i Regionalny, 12, 5-12.

Wang H., Yang Y., 2019, Neighbourhood walkability: A review and bibliometric analysis, Cities, 93, 43-61. (DOI 10.1016/j.cities.2019.04.015)

Yamagata Y., Seya H., 2019, Spatial Analysis Using Big Data, Methods and Urban Applications, Academic Press, Cambridge.

Yin L., Cheng Q., Wang Z., Shao, Z., 2015, "Big data" for pedestrian volume: Exploring the use of Google Street View images for pedestrian counts. Applied Geography, 63, 337-345. (DOI 10.1016/j.apgeog.2015.07.010) 